\title{
DINASTI POLITIK DALAM PEMERINTAHAN LOKAL STUDI KASUS DINASTI KOTA BANTEN
}

\author{
Winda Roselina Effendi \\ Program Studi Ilmu Pemerintahan, Fakultas Ilmu Sosial dan Ilmu Politik, Universitas Riau Kepulauan, \\ Indonesia \\ winda.effendis@gmail.com
}

\begin{abstract}
Abstrak
Dinasti politik dapat dipahami sebagai strategi politik untuk tetap menjaga kekuasaan dengan cara mewariskan kekuasaan yang telah digenggam kepada orang lain yang masih merupakan kalangan sanak keluarga, Pertama, macetnya kaderisasi partai politik dalam menjaring calon kepala daerah yang berkualitas, sehingga menciptakan pragmatisme politik dengan mendorong kalangan sanak keluarga kepala daerah untuk menjadi pejabat publik. Kedua, konteks masyarakat yang menjaga adanya kondisi status quo di daerahnya yang menginginkan kepala daerah untuk berkuasa dengan cara mendorong kalangan keluarga atau orang dekat kepala daerah menggantikan petahanan. Dinasti Politik merupakan ekses negatif dari otonomi daerah yang menjadikan demokrasi terbajak (hijacked democracy) oleh sirkulasi hubungan inti genealogis, berdasarkan relasi kekeluargaan maupun di luar garis genealogis yang memiliki kepentingan terhadap pelanggengan kekuasaan family. Dalam prakteknya sendiri aktualisasi dinasti politik dilakukan dengan beberapa sudut pandang yaitu neopatrimonialisme, klan politik, dan predator politik. Berkembangnya dinasti politik di tingkat lokal juga bisa ditafsirkan sebagai bentuk 'Cendanaisasi' lokal. Istilah cendanaisasi merujuk pada Keluarga Cendana semasa 32 tahun kepemimpinan Presiden Soeharto yang sangat berkuasa dalam ekonomipolitik Indonesia. Semua pos-pos kunci pemerintahan dikuasai anak, menantu, kemenakan, maupun kerabat lainnya, sehingga kekuasaan tersebut menjadi langgeng selama tiga dekade pemerintahan. Pola itulah yang sebenarnya sedang berkembang dan dicontoh oleh para keluarga elit lokal bahwa proses demokrasi lokal bisa ditelikung dengan menempatkan kerabat dalam posisi strategis daerah.

Kata Kunci: Politik local, Dinasti, Pemerintahan daerah.
\end{abstract}

\begin{abstract}
Political dynasties can be understood as a political strategy to maintain power by passing down the power that has been held by others who are still among relatives. First, the stagnation of the cadre of political parties in capturing qualified regional head candidates, thus creating political pragmatism by encouraging relatives the regional head's family to become a public official. Second, the context of the community that maintains the status quo conditions in the region that want the regional head to rule by encouraging the family or people close to the regional head to replace detention. Political dynasty is a negative excess of regional autonomy that makes hijacked democracy by the circulation of genealogical core relations, based on kinship relations and outside of genealogical lines that have an interest in perpetuating family power. In practice, the actualization of political dynasties is carried out with several perspectives, namely neopatrimonialism, political clan, and political predators. The development of political dynasty at the local level can also be interpreted as a form of local 'Cendanaisasi'. The term cendanaisasi refers to the Cendana Family during the 32 years of President Soeharto's leadership which was very powerful in Indonesia's political economy. All key government posts are controlled by children, sons-in-law, nephews, and other relatives, so that this power becomes lasting for three decades of government. This pattern is actually being developed and exemplified by local elite families that the local democratic process can be traced by placing relatives in regional strategic positions.

Keywords: Local Politics, Dynasty, Regional Government.
\end{abstract}




\section{PENDAHULUAN}

Secara harfiah, dinasti politik dapat dipahami sebagai strategi politik untuk tetap menjaga kekuasaan dengan cara mewariskan kekuasaan yang telah digenggam kepada orang lain yang masih merupakan kalangan sanak keluarga. Adapun berbagai gejala yang mendasari terbentuknya suatu dinasti menurut Wasisto (2013: 203) dapat dianalisis dari dua hal. Pertama, macetnya kaderisasi partai politik dalam menjaring calon kepala daerah yang berkualitas, sehingga menciptakan pragmatisme politik dengan mendorong kalangan sanak keluarga kepala daerah untuk menjadi pejabat publik. Kedua, konteks masyarakat yang menjaga adanya kondisi status quo di daerahnya yang menginginkan kepala daerah untuk berkuasa dengan cara mendorong kalangan keluarga atau orang dekat kepala daerah menggantikan petahanan.

Kedua gejala umum tersebut menimbulkan adanya sikap pro dan kontra dalam pemahaman dinasti politik tersebut. Sikap pro dan kontra kemudian berkembang menjadi perdebatan diskursus dalam revisi RUU Pilkada. Di satu sisi, ada pihak menginginkan pembatasan dinasti politik dengan cara membatasi sanak saudara kepala daerah untuk maju dalam Pemilukada, sementara yang lain mengusulkan dinasti politik tak perlu dilarang, hanya saja sistem kaderisasi partai politik di daerah perlu dibenahi.

Adanya sikap pro dan kontra terhadap kemunculan dinasti politik tersebut sangatlah erat kaitannya dengan budaya politik yang berkembang di masyarakat. Budaya politik sendiri berkaitan dengan preferensi kekuasan yang dibangun baik dari segi penerimaan publik maupun pembangunan rezim. Maka pertanyaan yang relevan dalam pembahasan dinasti politik adalah bagaimana karakteristik preferensi budaya politik berkembang dalam pembentukan politik dinasti. Adapun preferensi budaya pemilih erat kaitannya dengan perilaku memilih yakni kecenderungan pemilih untuk memilih berdasarkan sumber informasi yang ditangkap baik itu rasional maupun tradisional (Cesar, 2013).

Dinasti Politik merupakan ekses negatif dari otonomi daerah yang menjadikan demokrasi terbajak (hijacked democracy) oleh sirkulasi hubungan inti genealogis, berdasarkan relasi kekeluargaan maupun di luar garis genealogis yang memiliki kepentingan terhadap pelanggengan kekuasaan famili. Hal itulah yang kemudian memicu kalangan kerabat menjadi elit sebagai kata kunci pemahaman dinasti dalam praktek pemerintahan lokal (Syamsudin, 2007). Dalam prakteknya sendiri aktualisasi dinasti politik dilakukan dengan beberapa sudut pandang yaitu neopatrimonialisme, klan politik, dan predator politik. 


\section{MASALAH PENELITIAN}

Maraknya praktik politik dinasti menunjukan akar feodalisme dan tradisi monarki ditanah air yang belum banyak berubah. Saat ini, politik dinasti tengah menjadi trendi berbagai daerah di Indonesia. Praktik semacam ini harus segera dihentikan, bukan hanya bertentangan dengan semangat hakiki demokrasi, namun praktik politik dinasti berpotensi kuat menutup peluang masyarakat untuk menjadi pemimpin. Politik Dinasti telah ada dan telah berlangsung di Indonesia sejak Bung Karno berkuasa. Meskipun Politik Dinasti tidak melanggar peraturan berdemokrasi, dalam praktiknya namun dinasti politik menahan adanya mobilisasi sosial, sebab kekuasaan hanya diasosiasikan pada golongan masyarakat tertentu saja.

Fenomena dinasti politik dalam ranah lokal muncul seiring dengan diberlakukannya Pemilukada langsung pertama kali di Indonesia pada tahun 2005 maupun implementasi otonomi daerah tahun 2001. Seiring dengan berjalannya kedua proses tersebut sebagai wujud demokratisasi di tingkat lokal, berbagai elit bermunculan di daerah untuk mengkooptasi kedua proses tersebut (Wasisto, 2013). Kemunculan para elit dalam demokrasi lokal tersebut lazim dikenal dalam istilah reorganisasi kekuasaan. Reorganisasi ini diartikan sebagai kembalinya pengaruh kekuasaan politik elit lokal ke dalam era demokrasi. Selama Orde Baru berkuasa, kekuasaan para elit ini dibatasi oleh pusat yang lebih cenderung pada mekanisme pengangkatan maupun penunjukkan langsung. Hal inilah yang membuat elit lokal terbelah menjadi dua, yakni sebagai pelayan Orde Baru sehingga mendapatkan keistimewaan politik dan elit lokal penentang yang tidak menyukai kepemimipinan Orde Baru sehingga tersingkir dalam arena politik lokal di daerahnya.

Momentum transisi dari otoritarianisme menuju demokrasi yang kemudian ditandai dengan kebijakan otonomi daerah sangat dimanfaatkan oleh kedua kelompok elit untuk berkuasa secara penuh di daerahnya baik berkontestasi untuk menjadi elit pemenang maupun bersinergi satu sama lain yang pada umumnya disatukan melalui jalur perkawinan. Maka tidaklah mengherankan kemudian otonomi daerah melahirkan adanya raja-raja kecil di daerah. Berkembangnya dinasti politik di tingkat lokal juga bisa ditafsirkan sebagai bentuk 'Cendanaisasi' lokal. Istilah cendanaisasi merujuk pada Keluarga Cendana semasa 32 tahun kepemimpinan Presiden Soeharto yang sangat berkuasa dalam ekonomi-politik Indonesia. Semua pos-pos kunci pemerintahan dikuasai anak, menantu, kemenakan, maupun kerabat lainnya, sehingga kekuasaan tersebut menjadi langgeng selama tiga dekade pemerintahan. 
Pola itulah yang sebenarnya sedang berkembang dan dicontoh oleh para keluarga elit lokal bahwa proses demokrasi lokal bisa ditelikung dengan menempatkan kerabat dalam posisi strategis daerah.

Di Indonesia pada provinsi Banten, jejak-jejak dinasti politik lebih kentara. Ratu Atut Choisyah Gubernur Banten 2007-2012 misalnya, keluarga besarnya memiliki setidaknya 9 orang yang memimpin di masing masing "kerajaannya". Seperti dirinya sendiri yang memimpin Banten, suami menjadi anggota DPR, anak menjadi anggota DPD, menantu menjadi anggota DPRD Kota Serang, adik menjadi anggota DPRD Banten, Adik tiri mejadi wakil wali kota Serang, ibu tiri menjadi anggota DPRD Kabupaten Pandeglang, Ibu tirinya yang satu lagi menjadi anggota DPRD kota Serang, dan adik iparnya Airin menjadi Walikota Tangerang Selatan.

Dalam kajian ilmu sosial dan politik, familisme sebagai budaya politik diartikan sebagai ketergantungan yang terlalu besar pada ikatan keluarga, yang melahirkan kebiasaan menempatkan keluarga dan ikatan kekerabatan pada kedudukan yang lebih tinggi daripada kewajiban sosial lainnya. Dalam pengertian lainnya, familisme juga dipahami sebagai new social order, yakni dorongan psikologis bagi seseorang untuk dapat berkarir di dalam dua ranah yakni publik sebagai birokrat dan privat sebagai korporat-swasta (Garzon, 2002: 56).

Dalam hal ini, terdapat tiga varian familisme dalam membincangkan dinasti politik dalam konteks ini. Pertama adalah familisme (familism), yakni dinasti politik yang didasarkan secara murni pada hubungan darah langsung dalam keluarga (consanguinity) dan hubungan perkawinan (marriage) dengan klan lainnya. Bagi keluarga politik yang lebih lemah posisinya akan menguntung pada keluarga politik yang lebih kuat karena akan menjamin eksistensi keluarga politik lemah tersebut (Garzon, 2002: 4). Contoh kasus nyata dinasti politik model familisme ini seperti yang terjadi di Filipina, di mana terdapat 105 dinasti politik baik yang berkembang dalam ranah politik lokal maupun nasional.

Hal yang menarik adalah pengaruh kekerabatan tidak hanya berlangsung pada level legislatif maupun eksekutif, tetapi juga merambah ke arena yudikatif maupun aparat penegakan hukum lainnya. Kedua adalah quasi-familisme. Model ini didasarkan pada sikap afeksi dan solidaritas dari anggota keluarga dalam struktur kekuasaan.

Adapun afeksi yang dimaksudkan secara harfiah tidak dimaknai sebagai kasih sayang, namun sebagai bentuk orientasi politik keluarga didasarkan pada regionalisme, lingkungan, 
maupun tribalisme sama dengan keluarga tersebut (Tong-Hee, 2009). Ketiga adalah egoismefamilisme. Model dinasti politik ini didasarkan pada pemenuhan aspek fungsionalisme dibanding hanya menuruti garis keturunan maupun ikatan darah. Konteks egoisme ini dapat dipahami dalam dua hal, yakni dari segi kepala daerah dan masyarakat. Egoisme dari kepala daerah pada dasarnya sama dengan konsepsi teori sebelumnya yakni kecenderungan mendahulukan keluarga dari pada publik dalam pengisian posisi jabatan publik maupun suksesi pemerintahan (Tong-Hee, 2009: 126).

Tabel 1. Tipologi Perspektif Budaya Politik Familisme

\begin{tabular}{|c|c|c|c|}
\hline Indikator & Familisme & Quansi-Fasilisme & Ego-Familisme \\
\hline Dasar pembentukan & Hubungan Darah & Hubungan & Dorongan publik \\
\hline Dinasti Politik & Langsung (consanguinity) & $\begin{array}{l}\text { afeksi, solidaritas, } \\
\text { kepercayaan, dan } \\
\text { soliditas dalam } \\
\text { keluarga besar } \\
\text { maupun kroninya }\end{array}$ & $\begin{array}{c}\text { dan faktor } \\
\text { emosional dan } \\
\text { pertimbangan } \\
\text { politik fungsional }\end{array}$ \\
\hline Kaderisasi & $\begin{array}{l}\text { Anggota keluarga } \\
\text { inti dan kroni }\end{array}$ & $\begin{array}{l}\text { Sanak kerabat } \\
\text { maupun keluarga } \\
\text { lain melalui jalur } \\
\text { pernikahan yang } \\
\text { seketurunan } \\
\text { (hereditary) }\end{array}$ & Keluarga inti \\
\hline Sifat dinasti politik & Tertutup & Semi tertutup & Tertutup \\
\hline
\end{tabular}
Sumber: Asako (2010), Park (2009), dan Garzon (2002)

Dari pemaparan diatas, dinasti politik menjadi sebuah trend yang menarik untuk dikaji. Boleh jadi sebagian orang menganggap wajar hal tersebut muncul, namun sebagaian lagi menganggap hal itu distorsi atau tekanan terhadap demokrasi. Demokrasi yang pada dasarnya, menuntut transparansi dari semua proses politik tertekan oleh dinasti politik. Oleh karena itu wajar bilamana munculnya dinasti politik dianggap membahayakan kelangsungan demokrasi di Indonesia. Maka, bagaimana kelangsungan pemerintah lokal terhadap banyaknya praktek dinasti politik?

\section{KERANGKA TEORI}

Dinasti politik dalam dunia politik modern dikenal sebagai elit politik yang berbasiskan pertalian darah atau perkawinan sehingga sebagian pengamat politik menyebutnya sebagai oligarkhi politik. Dalam konteks Indonesia, kelompok elit adalah kelompok yang memiliki kemampuan untuk yang mempengaruhi proses pembuatan keputusan politik. Sehingga mereka kadang relatif mudah menjangkau kekuasaan atau bertarung merperebutkan kekuasaan. Sebelum munculnya gejala dinasti politik, kelompok elit tersebut diasosiasikan elit partai politik, elit militer dan polisi, elit pengusaha atau pemodal, 
elit agama, elit preman atau mafia, elit artis, serta elit Aktifis.

Menurut Pareto dalam Varma (2007 : 206) yang disebut dengan kelompok elit adalah sekelompok kecil individu yang memiliki kualitas-kualitas terbaik, yang dapat menjangkau pusat kekuasaan sosial politik. Elit merupakan orang-orang yang berhasil, yang mampu menduduki jabatan tinggi dalam lapisan masyarakat. Pareto meyakini bahwa elit yang tersebar pada sektor pekerjaan yang berbeda itu umumnya berasal dari kelas yang sama. Yakni orang-orang yang kaya dan pandai. Ia menggolongkan masyarakat kedalam dua kelas, lapisan atas (elite) dan lapisan bawah (non-elite). Lapisan atas atau kelas elit terbagi dalam dua kelompok, yakni elit yang memerintah (governing elite) dan elit yang tidak memerintah (non-governing elite). Sementara Gaetano Mosca menyebutkan bahwa di setiap masyarakat yang berbentuk apapun senantiasa muncul dua kelas, yaitu kelas yang memerintah dan kelas yang diperintah. Kelas yang memerintah memiliki jumlah yang sedikit, memegang semua fungsi politik, monopoli kekuasaan dan menikmati keuntungan- keuntungan yang didapatnya dari kekuasaan, yang kadangkadang bersifat legal, arbitrer, dan menggunakan kekerasan.

Mosca dalam Varma (2007: 204) meneliti komposisi elit lebih dekat lagi dengan mengenali peran 'kekuatan sosial' tertentu. Mosca mengenalkan konsep 'sub elite' yang merupakan kelas menengah dari para pegawai negeri sipil, para manajer industri, ilmuwan dan mahasiswa.

Adapun patronase tersebut diwujudkan dengan cara mengunci pos-pos penting dalam pemerintahan dan masyarakat oleh orang-orang terdekat. Hal ini dilakukan sebagai upaya meredam demonstrasi masyarakat karena sadar bahwa jumlah elit tunggal ini sebenarnya lebih sedikit sehingga cara itu dilakukan untuk mengefektifkan kekuasaan. Sedangkan makna elit pluralis lebih dinamis dibandingkan dengan elit tunggal yang sangat statis. Elit pluralis diartikan sebagai jejaring antar elit dalam konteks berbagi kekuasaan dalam ekonomidan politik (Haryanto, 2007). Hal ini sekaligus juga sebagai koreksi atas elit tunggal yang jumlahnya kecil sehingga rawan terjadinya pergolakan kemasyarakatan.

Monopoli dengan mengunci pos jabatan politik formal dalam pandangan elit pluralis tidaklah tepat dalam menghadapi dinamika masyarakat. Akan lebih baik jika logika elit sendiri dijalankan dalam kerangka oligopoli. Artinya, kontrol atas sumber kekuasaan tetap dijalankan namun juga mengundang aktor lain untuk masuk dalam jejaring elit tersebut. Elit pada dasarnyabersifat jamak dan berganti-ganti pada setiap tahapan fungsionaldalam proses pembuatan keputusan dan perannya bisa naik turuntergantung situasinya. Artinya, status elit 
ini bukanlah suatukeajegan yang didapatkan dalam hubungan askriptif, namun bisa melekat kepada siapa saja yang kebetulan mempunyai peran penting (Soelaiman 1998).

Pemahaman lain, dinasti politik sebagai bentuk politik keluarga (political clan) digunakan Kreuzer (2005) dan Cesar (2013). Dinasti politik muncul sebagai ekses dari warisan feodalisme yang masihmenancap kuat di masyarakat. Feodalisme yang dimaksudkan bukan hanya penguasaan sumber daya ekonomi saja, tetapi juga terbentuknya jejaring loyalitas dalam masyarakat dengan melibatkan para tokoh informal.

Seperti yang terdapat dalam kasus Filipina Selatan, dinasti politik muncul karena sistem institusionalisasi politik maupun penegakan hukum yang lemah karena kooptasi kekuatan klan politik. Bahkan, dinasti politikdi sana sudah berkembang layaknya monarki politik dengan memilikimilisi bersenjata sendiri yang digunakan untuk mengintimidasi warga.

Kekuatan negara di pemerintahan lokal melemah karena kontrol klan politikyang tersebar baik di jajaran eksekutif, yudikatif, maupun legislatif. Maka dalam taraf ini, dinasti politik sudah berkembang seperti "negara dalam negara" (state qua state) dalam sistem politik yang lemah. Ketiga yakni kajian dinasti politik sebagai bentuk praktik politik predator. Pemahaman politik predator sendiri merupakan pengembangan tesis Migdal (1988) mengenai local strongmen maupun Sidel (2005: 23) tentang local bossism.

Studi pendekatan ini dilakukan oleh Asako (2010) dan McCoy (1994) yang menganalisis tumbuhnya dinasti politik justru terjadi karena adanya kolusi bisnis-politik ditingkat lokal. Dalam hal ini, jejaring keluarga telah menguasai berbagai proyek pembangunan daerah yang kemudian dibagi-bagikan kepada kroni-kroninya. Dinasti politik berperan sebagai patron dalam menjaga stabilitas kolusi tersebut dengan menempatkan sanakfamilinya ke dalam jajaran perusahaan maupun pemerintahan. Oleh karena itu, praktik penjarahan ekonomi berlangsung secara terus-menerus karena praktiknya selalu dilakukan oleh jejaring elit keluarga. Perspektif dinasti politik sebagai bentuk kartel local strongmen dan local bossism yang meneliti tentang adanya pengaruh seorang elityang secara individual membangun hubungan patrimonialistik dalam masyarakat maupun negara. Dalam hal ini, dinasti politik merupakan bentuk kolektif dari patronase elit dalam wujud kolektif yang didasarkan pada hubungan famili, etnisitas, maupun hubungan darah lainnya yang intinya memunculkan monarki dalam demokrasi tingkat lokal. 
Namun kemudian bagaimana kita menempatkan dinasti politik sebagai bagian dari proses input dalam transisi demokrasi yang tidak sempurna. Adapun yang dimaksudkan dengan input dalam konteks ini adalah bagaimana sumber-sumber kekuasaan dinasti politik tersebut dibangun melalui kekuatan keluarga sehingga dapat berkembang menjadi kartel politik yang besar. Dalam hal ini, terdapat tiga karakteristik mendasar dalam menganalisis dinasti politik.

Pertama, fungsi partai politik yang melemah di aras lokal karena terkooptasi oleh para elit daerah. Pada akhirnya timbul sikap pragmatisme dari partai politik dengan cenderung mengangkat elit dan keluarganya menjadi pejabat publik daerah.

Kedua, neo-feodalisme yang menguat di daerah, yakni revitalisasi kekuatan tradisional dalam arena politik modern yang berbasis tribalisme, regionalisme, premanisme, dan lain sebagainya.

Ketiga, biaya politik yang mahal dalam setiap Pemilukada mereduksi partisipasi politik aktif dari masyarakat. Demokrasi lokal yang esensinya menjembatani partisipasi politik aktif maupun pasif masyarakat justru terjebak dalam logika demokrasi yang mahal baik dalam proses pengajuan kandidat hingga pemilihan (Harjanto 2011).

\section{PEMBAHASAAN}

\section{PROSES TERBENTUKNYA DINASTI POLITIK DI PEMERINTAHAN LOKAL}

Secara umum, basis fondasi kekuasaan formal dinasti politik lokal di Indonesia dibangun berdasarkan hubungan paternalistik melalui redistribusi progam populis yang dihasilkan melalui skema politik 'gentong babi' (pork barrel politics) maupun politisasi siklus anggaran (politic budget cycle). Hal itulah yang kemudian mendorong adanya hubungan kedekatan maupun romantisme antara pemimpin dengan rakyatnya sehingga pemimpin mudah dalam membentuk politik persuasif melalui gelontoran uang hingga ke pelosok.

Berkaitan dengan suksesi kepemimpinan, politisasi birokrat maupun sosialisasi tokoh informal masyarakat menjadi bagian intimitas yang bertindak sebagai agen intermediasi dalam memenangkan dan melanggengkan kekuasaan famili politik. Perbincangan mengenai dinasti politik dalam ranah politik lokal sangatlah berbeda dengan konteks dinasti politik yang terjadi di level nasional. Dalam ranah lokal, romantisasi nama besar familisime menjamin suatu dinasti politik dapat eksis secara terus-menerus. Familisme sendiri dibentuk 
atas tiga hal, yakni figur (personalism), klientelisme (clientelism), dan tribalisme (tribalism), sebagai ketiga kunci dalam mengurai basis-basis terbentuknya tren familisme kekuasaan dalam demokrasi lokal di Indonesia (Allen, 2012: 6-7).

Ketiga proses tersebut berperan besar dalam suksesi pemerintahan lokal di Indonesia yang dilakukan dalam dua jenis yakni secara by design dan by accident. Dinasti politik yang by design sudah terbentuk sejak lama dimana jejaring familisme dalam pemerintahan sendiri sudah kuat relasionalnya sehingga kerabat yang ingin memasuki kancah pemerintahan maupun politik sudah didesain sejak awal untuk menempati pos tertentu. Adapun by accident sendiri terjadi dalam situasi suksesi pemerintahan yang secara tiba-tiba mencalonkan kerabat untuk menggantikannya demi menjaga kekuasaan "informal" terhadap penggantinya kelak jika memang dalam Pemilukada.

Dalam mayoritas kasus Pemilukada di Indonesia sendiri, suksesi kekuasaan berbasis familisme ada yang dilakukan secara by accident maupun by design di berbagai kabupaten/kota. Model by design yang dominan adalah istri yang maju menggantikan suami atau anak menggantikan bapaknya. Sementara itu, model by accident adalah kerabat sebagai calon kepala daerah hanya sebagai bayangan atas kerabat lain yang difavoritkan akan memenangkan Pemilukada. Pola pengajuan kandidat tersebut biasanya dilakukan secara sporadis untuk menghalangi calon lain maju dalam proses pengajuan kandidat. Dapat dikatakan bahwa intimitas hubungan keluarga kemudian menjadi platform politik guna mengamankan kekuasaan daerah.

Pola suksesi aksidental dalam model dinasti politik seperti ini kerap kali memunculkan anekdot kuasa gono-gini ataupun 'arisan kekuasaan' karena transisi kekuasaan daerah hanya terjadi di dalam satu rumah saja. Selain itu, tren familisme dalam dinasti politik aksidental seperti ini tidak akan bertahan lama. Hal ini karena regenerasi kekuasaan tidak dilakukan secara matang, melainkan hanya mengejar pragmatisme politik belaka. Asumsi lainnya dari tren famili aksidental ini juga kerabat yang dicalonkan menjadi kepala daerah biasanya belum memiliki kapabilitas kuat dalam membangun daerahnya. Publik hanya akan menilai bahwa kerabat yang dicalonkan merupakan bayang-bayang dari kepala daerah sebelumnya sehingga sangatlah sulit bagi calon kepala daerah melepas pencitraan tersebut.

Pertama-tama, yang perlu diletakkan terlebih dahulu dalam membahas perkembangan dinasti politik di daerah adalah memerhatikan jaringan kekuasaan terbentuk dalam ranah formal dan informal yang umumnya terjadi dalam nalar ekonomi-politik. Hal tersebut 
dilakukan kepala daerah sebelum pada langkah berikutnya mulai menempatkan kerabatnya sebagai proyek dinasti politik. Adapun jejaring kekuasaan kepala daerah tersebut dibangun atas sinergitas birokrasi, kapitalis, dan politisi yang membentuk jaringan kuasa formal dan informal dalam masyarakat aras lokal. Secara garis besar, konteks budaya politik familisme yang berlangsung dalam ranah politik lokal lebih mengarah pada proses figurisasi sebagai daya tarik pemilih yang kemudian dikomodifikasi menjadi dasar politis seseorang untuk menarik kerabatnya dalam lingkaran kekuasaan. Selain figurisasi, faktor lain yang memengaruhi pembentukan preferensi politik familisme yaitu faktor afeksional, seperti kepercayaan (trust), solidaritas (solidarity) maupun soliditas (solidity) yang secara keseluruhan turut menentukan eksistensi dinasti politik, baik antara anggota internal keluarga maupun kroni-kroni yang berada dalam lingkar kekuasaannya. Dalam hal ini, perspektif budaya politik familisme sudah mengafirmasi berbagai gejala umum yang berkembang dalam mendasari dinasti politik.

\section{BENTUK DINASTI POLITIK PADA PEMERINTAHAN LOKAL DAERAH BANTEN}

Jejak budaya politik familisme di dalam dinasti politik lokal dapat ditelusuri melalui pemetaan sumber-sumber kekuasaannya. Pemetaan menjadi sangat penting dan signifikan dalam menelisik karakteristik bangunan dinasti politik yang berbeda di setiap daerah. Perbedaan tersebut didasari atas berbagai macam hal, seperti faktor lingkungan, demografis, sejarah, dan adat-istiadat. Tipologi dalam konteks ini juga untuk memberikan telaah mengenai kecenderungan politis yang menjadi dominan dalam membentuk pemerintahan dinasti. Setidaknya terdapat empat tipologi preferensi familisme dalam dinasti politik lokal yang akan dibahas dalam sub-tulisan ini, yakni familisme berbasis populisme, tribalisme, jejaring kuasa informal, dan feodalisme. 
Tabel 2. Tipologi Rezim Dinasti Politik di Indonesia

\begin{tabular}{|c|c|c|c|}
\hline $\begin{array}{c}\text { Tipologi Dinasti } \\
\text { Politik }\end{array}$ & $\begin{array}{c}\text { Dasar } \\
\text { Pembentukan }\end{array}$ & $\begin{array}{c}\text { Karakter } \\
\text { Rezim }\end{array}$ & $\begin{array}{c}\text { Contoh } \\
\text { Kasus }\end{array}$ \\
\hline Populism Dynasties & $\begin{array}{l}\text { Figur merakyat dan program } \\
\text { populis, menjaga status quo, } \\
\text { dibentuk secara by incident } \\
\text { Patrimonialisme, } \\
\text { kharismatik figur, sinergi }\end{array}$ & $\begin{array}{l}\text { Semi-terbuka, } \\
\text { populis dan kuasa- } \\
\text { otoritarian }\end{array}$ & $\begin{array}{c}\text { Bantul, } \\
\text { Kendal,probolinggo } \\
\text { Dan Indramayu }\end{array}$ \\
\hline Octopussy Dynasties & $\begin{array}{l}\text { aktor formal dan informal, } \\
\text { korporatisme masyarakat, } \\
\text { dibentuk secara by design } \\
\text { Reproduksi ritus-ritus } \\
\text { budaya etnis,ikatan }\end{array}$ & $\begin{array}{l}\text { Tertutup,oligarkis, } \\
\text { Semi-demokrasi }\end{array}$ & Banten \\
\hline Tribalism Dyanasties & $\begin{array}{c}\text { primodialisme, klan politik, } \\
\text { stratifikasi sosial } \\
\text { Kesejarahan, berstatus } \\
\text { mantan kerajaan }\end{array}$ & $\begin{array}{c}\text { Tertutup dan } \\
\text { Primodialistik }\end{array}$ & $\begin{array}{l}\text { Sulawesi Utara, } \\
\text { Sulawesi Selatan } \\
\text { dan Papua }\end{array}$ \\
\hline Feudalism Dynasties & & $\begin{array}{c}\text { Tertutup dan } \\
\text { Patrimonalistik }\end{array}$ & DIY dan Bali \\
\hline
\end{tabular}

Pada Kasus Banten adalah dinasti politik berbasis jaringan kuasa. Model dinasti politik ini nampak dalam kasus Banten pasca otonomi daerah. Syarif Hidayat (2007) menegaskan bahwa dinasti politik Banten ini terbangun atas koalisi klan politik, monopoli ekonomi, kekerasan, dan sebagainya. Kondisi itu sangat mirip dengan klan Ampatuan yang berada di kawasan Mindanao Selatan, Filipina, di mana anggota keluarganya memegang jabatan publik yang berpengaruh dan sudah berakar lebih dari 200 tahun. Kasus dinasti politik Banten merupakan contoh utama dinasti politik yang dirancang by design oleh para kerabatnya untuk terjun ke dunia politik. Dinasti politik Banten telah berdiri kokoh seiring dengan usia Provinsi Banten sehingga jaringan kekuasaan telah tersebar kuat di pemerintahan. Dengan kata lain, desain dinasti politik Banten bernuansa aji mumpung dengan mendompleng kekuasaan kerabat.

Kondisi tersebut kontras dengan rezim populism oligarchy yang suksesi pemerintahannya bersifat insidental. Dalam konteks ini, aji mumpung adalah kerabat bertindak menjadi patron bagi kerabat lainnya ketika memasuki ranah pemerintahan. Indikasinya bisa disimak dengan kerabat gubernur Banten yang bertebaran menjadi penjabat publik di ranah legislatif maupun eksekutif. Namun demikian, patron sebenarnya dalam dinasti politik Banten ini adalah Tubagus Chasan Sochib dengan "kelompok Rawu”-nya yang sebenarnya merupakan nama kawasan pasar di Kota Serang (Karomah, 2008). Akan tetapi, Rawu dalam pemahaman publik Banten merupakan sebutan bagi kelompok bisnis atau dinasti keluarga Chasan Sochib yang menguasai pemerintahan Banten. 
Dinasti Banten berdiri dalam beberapa ranah yakni ekonomi, sosial-budaya, religus, dan tentu saja politik. Ditinjau dari akar historisnya, sebenarnya Chasan Sochib merupakan pengusaha biasa. Hanya saja, nasib baik berpihak kepadanya dengan menjalin hubungan erat dengan perwira militer dan petinggi Golkar Banten yang dulunya merupakan penguasa lokal Banten pada zaman Orde Baru. Pasca otoritarian runtuh, Chasan Sochib juga merupakan aktor utama terbentuknya Provinsi Banten dan bertindak sebagai aktor di balik layar atas pemerintahan lokal dengan membentuk Persatuan Pendekar Persilatan dan Seni Budaya Banten Indonesia (PPPSBBI) sebagai organisasi penampung Jawara/jagoan Banten, Satuan Kerja Ulama (Satkar Ulama), maupun Satuan Kerja Pendekar (Satkar Pendekar) sebagai organisasi kemasyarakatan yang berpengaruh besar dalam struktur masyarakat Banten (Hamid, 2010: 37). Dalam ranah ekonomi, Chasan sukses merengkuh jabatan sebagai Ketua Kadin Banten, Ketua Gabungan Pengusaha Konstruksi Nasional Indonesia (Gapensindo) Banten, dan Ketua Lembaga Pengembangan Jasa Konstruksi Nasional (LPJKN) Banten.

Langkah pertama membangun dinasti politik dilakukan dengan cara menempatkan Ratu Atut Chosiyah sebagai Gubernur Banten selama dua periode yang kemudian diikuti oleh anak, menantu, dan cucunya yang kemudian menjadi pejabat eksekutif maupun legislatif di pemerintahan lokal. Seperti yang diutarakan sebelumnya bahwa dinasti politik ini terbangun atas logika aji mumpung yang sudah didesain untuk ditempati klannya. Masuknya keluarga dalam politik sendiri bukanlah dilakukan atas dasar sukarela (by consent) seperti yang terjadi dalam kasus populism dynasties di Bantul, Kendal, maupun Indramayu, namun lebih dimaknai sebagai atas dasar kehormatan (by honor) menjaga eksistensi pengaruh keluarga (Mc Coy 1994). Hal tersebut bisa kita simak dari anak gubernur yang statusnya masih mahasiswa pada 2009 didorong menjadi anggota DPD. Logika kehormatan belum tentu liner dengan kapabilitas dan manajerial politik sehingga kontribusi kepada masyarakat Banten sendiri hanya sebatas simbolisme saja. Selain itu, dinasti politik Banten juga sukses memanfaatkan saluran patrimonalisme yang dibangun oleh jawara dan ulama sebagai aktor penguasa tradisional di Banten.

Kedua aktor tersebut berfungsi sebagai pengontrol moral kemasyarakatan sekaligus juga penjaga keamanan dan ketertiban. Indikasinya dapat terlihat dari jawara yang beranjak dari mulanya pelindung masyarakat selama era kolonialisme kini menjadi aktor ekonomi informal di Banten. Pola sinergis antara jawara dan ulama di Banten ini kemudian mengukuhkan kekuasan karismatik dan simbolik guna menopang dinasti Banten. Model 
dinasti Banten ini layaknya tentakel gurita menjalar ke berbagai arah untuk menempatkan kroni maupun keluarganya masuk dalam berbagai posisi jabatan publik di Propinsi Banten yang tujuannya meningkatkan soliditas dan solidaritas masyarakat.

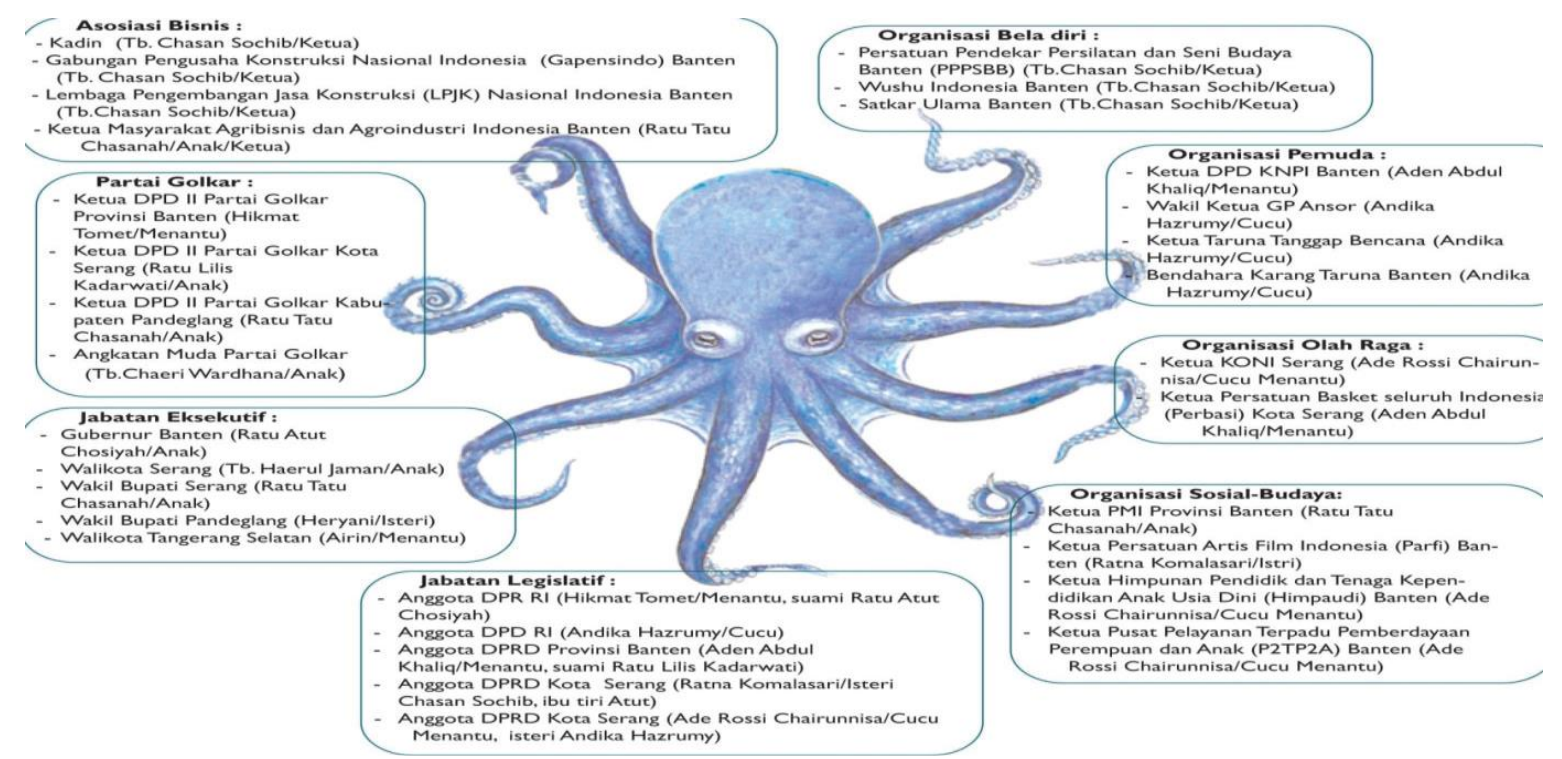

Gambar 1. Dinasti Politik Banten

Sumber: Konstelasi (2011:3)

Keberadaan dinasti politik yang kini bermunculan di daerah nampaknya membuat Kemendagri mulai memasukkan isu tersebut menjadi kajian akademik RUU Pemilukada yang kini tengah dibahas bersama Komisi II DPR RI. Pelarangan tentang adanya kerabat maju bersamaan dalam pemilu daerah tertuang pada pasal 70 huruf $p$ dan pasal 12 huruf $p$, di mana gubernur maupun bupati/walikota ditetapkan jika tidak mempunyai ikatan perkawinan, garis keturunan lurus ke atas, ke bawah, dan ke samping, sama halnya dengan gubernur, kecuali jika ada selang waktu dengan gubernur. Hal yang mendasari terciptanya kedua pasal tersebut adalah pendirian kepala daerah yang tidak netral jika kerabatnya maju dalam Pemilukada sehingga rawan terjadinya politisasi anggaran oleh kepala daerah demi pemenangan kerabatnya. Namun demikian, kedua pasal tersebut bisa saja rawan digugat karena landasan konstitusionalnya belum kuat dan lebih dikarenakan proses reaktif atas merebaknya dinasti politik lokal karena mencederai hak-hak politik warga negara dalam pemilu. Oleh karena itu, RUU tersebut perlu lebih dipertegas makna pelarangan tersebut karena bahasanya masih multitafsir dan belum memiliki dasar hukum yang kuat. 


\section{KESIMPULAN}

Kehadiran dinasti politik dalam konteks otonomi daerah dan demokratisasi memang menimbulkan masalah kepemimpinan diaras lokal. Masalah utama adalah stagnasi kepemimpinan dan minimnya partisipasi publik karena semua dikuasai elit. Kerawanan praktik korupsi karena seluruh kerabat cenderung saling menjaga praktik tersebut. Selain itu, terjadi kapitalisme klientelistik sebagai bagian dari kronisme, di mana pelaku investasi ekonomi tidak serta merta bebas melakukan aktivitasnya karena senantiasa dimintai upeti oleh kerabat kepala daerah. Demokratisasi yang memberikan kuasa kepada rakyat justru dinegasikan oleh rezim oligarkis di daerah yang kian berkembang. Tidak hanya itu, otonomi daerah memberi ruang besar bagi bangkitnya kekuatan lokal untuk menjadi pemain utama. Masalah yang timbul kemudian adalah masyarakat lokal hanya menjadi penonton dalam demokratisasi dan otonomi daerah di daerahnya.

Secara garis besar, gejala yang timbul dalam proses demokratisasi lokal adalah proses reorganisasi kekuatan tradisional untuk berkuasa di daerah dalam arena demokrasi. Revitalisasi kekuatan politik tradisional tersebut tumbuh seiring dengan proses otonomi daerah sehingga kelompok elit mendapat kesempatan untuk mengukuhkan pengaruhnya kembali. Selain adanya revitalisasi kelompok politik tradisional, gejala lain yang timbul dalam proses demokratisasi lokal adalah fungsi partai politik yang melemah dalam melakukan kaderisasi sehingga menimbulkan adanya pragmatisme politik dengan mengangkat para kelompok elit tersebut. Hal itu juga diikuti proses demokrasi yang mahal di mana masyarakat memilih pasif dalam proses demokrasi dan lebih cenderung menghendaki status quo pemerintahan sekarang. Sementara itu, kepala daerah memiliki tren untuk mewariskan kekuasaannya kepada kerabat demi menjaga kekuasaan dan menutupi aib politik. Semua itu mengkondisikan terbentuknya dinasti politik di ranah lokal. Dinasti politik mengandalkan kekuatan personal, klientelisme, dan relasi patrimonial yang menempatkan elit di atas masyarakat. Pada level ini, familisme kemudian mengorganisasikan diri menjadi dinasti politik untuk menjaga kelanggengan kuasa dan mengontrol sepenuhnya suara masyarakat. 


\section{DAFTAR PUSTAKA}

Wasisto, Raharjo Djati. (2013). Revivalisme kekuatan familisme : dinasti politik di aras lokal. Jurnal Sosiologi masyarakat. 18 (2).

Cesar, Julius. (2013). Political Dynasties in Indonesia and The Philippines. RSIS commentary.

Syamsudin, Haris. (2007). Pemilu Langsung di tengah Oligarki Partai. Jakarta: Gramedia Pustaka Utama.

Garzon, Adela. (2002). "Familism.” hal. 1-4, dalam International Encyclopedia of Marriage and Family, diedit oleh En J. Ponzetti. New York: MacMillan dalam Raharjo Djati Warsito.

Tong-Hee, Park. (2009). "The Influence of Familism and Interpersonal Trusts of Korean Public Officials". International Review of Public Administration.

Haryanto. (2007). Kekuasaan Elite: Suatu Pengantar. Yogyakarta: PolGov Press

Sidel, John. (2005). "Bosisme dan Demokrasi di Filipina, Thailand dan Indonesia" in Politisasi Demokrasi Politik Lokal Baru, edited by John Hariss. Jakarta: Demos.

Allen, Nathan. (2012). Clientelism and the Personal Vote in Indonesia. Ottawa: CPSA.

Hidayat, Syarif. (2007). Shadow State” Bisnis dan Politik di Provinsi Banten. hal. 267-303, dalam Politik Lokal di Indonesia, diedit oleh H.S Nordholt dan G.v. Klinken. Jakarta: Yayasan Obor Indonesia.

Karomah, Atu. (2008). Jawara dan Budaya Kekerasan di Banten, Al-Qalam. 25(3):25-40.

Hamid, Abdul. 2010. "Memetakan Aktor Politik Lokal Banten Pasca Orde Baru," Jurnal Politika. 